\title{
The Social and Pedagogical Qualities of Modern Vocational Training Teachers
}

Inna Imamovna Sokolova et all. / editor3@academicpapers.org Kazan Federal Univerzity, Kazan, Republic of Tatarstan, Russia.

Sokolova, I. I. - Ilina, M. S. - Vildanova, E. M. - Aydarova, A. M. - Strakhova, I. V. (2017). The Social and Pedagogical Qualities of Modern Vocational Training Teachers. Czech-Polish Historical and Pedagogical Journal, 9/2, 77-83.

doi: 10.5817/cphpj-2017-0015

The relevance of the research problem is determined by its practical and theoretical components. The practical relevance of the problem is determined, on the one hand, by new demands of society and industry on the pedagogical component of the vocational training teachers' activity, and by need to realize the potential of Humanities in development of the pedagogical competence of future vocational training teachers and the insufficient development of pedagogical conditions promoting the effective implementation of this process, on the other hand.

Key words: Pedagogical competence; Vocational training teacher; Humanities; Social and pedagogical qualities of vocational teachers

\section{Introduction}

Vocational training teachers play a leading role in solving the urgent problem of preparation of graduates to the adequate professional multifunctional activity. The level of training of a vocational training teacher depends largely on the quality of industrial (practical) training, the level of professional development of young specialists. Nowadays, a modern vocational training teacher's mission is to prepare a specialist who would integrate a knowledge not only revealing the patterns of development and realization of the personality in the modern world, but also necessary for the successful performance of professional functions. ${ }^{1}$

The aim of our research is to reveal the professionally important qualities of modern vocational training teachers. This problem has received considerable attention in national scholarly literature; teacher's

1 Gilmeeva, R. Kh. - Volovich, L. A. - Tikhonova, L. P. - Garaeva, N. G. Mukhametzyanova, L. U. - Bagavieva, G. M. (2009). Formirovanie klyuchevykh professionalnykh kompetentsiy studentov $\vee$ uchrezhdeniyakh srednego professionalnogo obrazovaniya $v$ protsesse prepodavaniya gumanitarnykh distsiplin. In Kazanskiy pedagogicheskiy zhurnal, nr. 1, pp. 75-90. 
professionally important qualities were studied in detail by a great number of researchers, such as Gonoblin, ${ }^{2}$ Grokholskaya and Nikandrov, ${ }^{3}$ Kuzmina, ${ }^{4}$ Syritso and Trusov, ${ }^{5}$ and others. However, this research aims at identifying the qualities important directly for the vocational training teacher, in order to incorporate key qualities and concepts in the structure of pedagogical competence, to develop its major components.

This objective has been attained through a theoretical analysis of the scientific literature on the subject, an ascertaining experiment comprising a questionnaire survey, and statistical analysis of the research results.

\section{Methods}

The leading scientific approach of the study was the competence approach, which constitutes a scientific and methodological basis for formation a number of general and professional competencies of future vocational training teachers. This approach enables them to master new skills in the future, be mobile, competitive and be the most in-demand on the modern job market.

Application of the interview-diagnostic method, particularly the survey and statistical processing of the obtained results, has allowed generalizing the empirical research data and drawing conclusions presented in the article.

\section{Results}

In the course of ascertaining experiment it was important to formulate the basic components of the pedagogical competence inherent to the vocational training teacher, so the author conducted a survey of 240

2 Gonobolin, F. N. (1968). Rol lichnosti uchitelya. In Narodnoe obrazovanie, nr. 6, pp. 69-73.

3 Grokholskaya, O. G. - Nikandrov, N. D. (2011). Vvedenie v professionalnuyu deyatelnost. Uchebnoe posobie dlya vuzov. Moscow: Drofa.

4 Kuzmina, N. V. (1990). Professionalizm lichnosti prepodavatelya i mastera proizvodstvennogo obucheniya. Moscow: Vysshaya shkola.

5 Syritso, T. G. - Trusov, V. P. (1987). Osobennosti emotsionalnosti uchitelya i uspeshnost ego deyatelnosti. In Eksperimentalnaya i prikladnaya psikhologiya. Vyp. 12: Psikhologicheskoe obespechenie trudovoy deyatelnosti. Leningrad: Leningrad State University Press, pp. 114-118. 
vocational training teachers from 5 professional colleges of Tatarstan and Russia (Chistopol Pedagogical College, Bugulma Pedagogical College, Kazan State Professional Pedagogical College, Kazan Aviation Technical College named after P. V. Dementiev, Smolensk Industrial and Economic College). What is the personality of a modern vocational training teacher? The results show that the modern vocational training teacher has the following distinctive characteristics: basically, it is a woman (86.25\%), aged 31 to 40 years (24.17\%), with higher education (93.33\%), mostly pedagogical $(56.67 \%)$ or technical $(23.33 \%)$, and teaching experience over 10 years $(34.17 \%)$.

Comparing the results with similar studies of G. I. Ibragimov 6 and G. A. Shaikhutdinova, ${ }^{7}$ it can be assumed that the trend of feminization of Russian education is maintained $-86.25 \%$ of 240 vocational training teachers are women and only $13.75 \%$ are men. As for the age, distribution is as follows: aged $21-30$ years $-12.50 \%$, aged $31-40$ years $-24.17 \%$, aged $41-50$ years $-22.50 \%$, at the age of $51-60$ years $-20.00 \%$, aged $61-70$ years $-10.83 \%$. Thus, there is a tendency of "rejuvenation" of specialists (increasing the age group 21-30 years from 5.60 to $12.50 \%$ ) indicating increased prestige of the teaching profession for young people.

It should be noted that $53.33 \%$ of teachers chose a profession deliberately and consider teaching their mission, $13.33 \%$ of respondents followed their parents' advice and continued the family teaching tradition, and $27.50 \%$ chose as a response "other". It is believed that if the choice is made consciously and a person carries out his/her mission, the work brings moral satisfaction. Answers to the question "Does your work bring you moral satisfaction?" proved this idea: $47.08 \%$ of respondents answered positively, $50.42 \%$ answer "Yes, but not in full", and only $0.83 \%$ of the respondents answered "No", 1.67\% work because of money.

The statement that vocational training teachers are active, creative, well-educated people who constantly upgrade their skills and are deeply interested in their professional development, is confirmed by the fact that $82.5 \%$ of respondents attended a variety of training courses over the past 5 years. Only $17.5 \%$ of them did not attend such courses due to the fact that they work in the field of education less than 3 years. It should be

6 Ibragimov, G. I. (ed.) (2003). Monitoring v sisteme usloviy obespecheniya kachestva podgotovki spetsialistov srednego zvena: Nauchno-pedagogicheskoe posobie dlya rabotnikov sistemy SPO. Kazan: Shkola.

7 Shaikhutdinova, G. A. (2004). Otnoshenie pedagogov tekhnikumov k professii i rabote. In Spetsialist, nr. 1, pp. 34-35. 
noted that teachers undergo further training on their own initiative with great desire and interest: $19.58 \%$ of the respondents attended courses 5 times or more during their work in vocational education, $24.17 \%-3-4$ times, and $37.92 \%-1-2$ times. A modern teacher is a highly qualified specialist who keeps up with the times and strives to correspond to modern requirements to the educational process, as evidenced by the theme of training courses selected by teachers - "humanitarian problems of our time", "educational activity", "innovative activity in education", as well as "modernization of modern education".

Our respondents teach Humanities (35.42\%) and professional subjects $(64.58 \%)$. There are a lot of vocational training teachers with high qualifying categories: the highest $-38.75 \%$, the first $-23.33 \%$, the second $-16.25 \%$, no category $-21.67 \%$. At the same time, number of vocational training teachers with a scientific degree $(1.67 \%)$ is rather low, which can be explained by the fact that obtaining a degree is not encouraged financially and rarely promotes teachers in their career in the field of secondary vocational education. However, the training courses cannot fully replace the scientific training of postgraduate studies, as well as to generate research competence required nowadays for a vocational training teacher. More than half of teachers have different kinds of publications (59.58\%): scientific publications - 22.50\%, methodical $36.25 \%$, educational - methodical complexes - $26.25 \%$. Vocational training teachers are involved in activities aimed at experience exchange and skills improving: $64.17 \%$ respondents participate in scientific conferences, $81.25 \%$ - in tutorial workshops, $57.08 \%$ - in roundtables, only $3.33 \%$ of respondents do not participate in such activities.

Analysis of the impact of humanities on the formation of professionally important qualities of future vocational training teachers' is impossible without revealing the attitude of modern vocational training teachers to Humanities. This hypothesis is confirmed by the responses to the question "Have Humanities influenced on your world view?". The answer was positive in $78.33 \%$ cases, and only $21.67 \%$ respondents answered negatively. Among the disciplines that were claimed to greatly influence professional education of vocational training teachers, the following disciplines should be mentioned: native and foreign literature (39.17\%), philosophy (30.42\%), economy (20.42\%), foreign languages (18 33\%), other disciplines (79.58\%), including the Russian and Tatar languages, history, sociology, political science, law, social studies, music, aesthetics, art, world culture. According to the results of the survey, the level of proficiency in foreign languages among respondents is poor, since $22.50 \%$ respondents do not speak any foreign language. Those teachers 
who claimed to know a particular language (English - 46.25\%, German $27.08 \%$, French $-5.00 \%$, other $-1.67 \%$ ) often noted that they cannot communicate and are only able to read and translate texts with a dictionary. However, sociability formed in the course of foreign language learning is an important component of pedagogical competence of vocational training teachers. Graduates of vocational colleges are expected to demonstrate competence in foreign languages to the extent defined by communication needs of their future profession. If students master a foreign language, they acquire language as a tool of professional culture more quickly and effectively master the language. The results of the study suggest that the Humanities have a tremendous impact on the formation of a person's worldview (78.33\% answer "yes"). Humanities form the personal qualities required for a successful performance of professional functions under a free market economy. Integrated with professional knowledge, Humanities reveal patterns of development and realization of the personality in the modern world and in professional activities.

Survey data indicate that the teacher is a central figure in solving problems of training and education, the level of graduates' training depends on his/her personal qualities and professional competences. When asked, "What is the role of each of these conditions in the process of improving training in colleges?", teachers answered, in order of importance: a high level of teachers training $-50.42 \%$, good organization of the educational process $-34.58 \%$, a modern material and technical base $-16.25 \%$, individual educational work $-10.83 \%$. These responses indicate that vocational training teachers of the high pedagogical competence, constantly improving the quality of their work are the most competitive in the field of vocational education.

Professionally important qualities are usually considered as the factors that determine the professional success and competitiveness. Surveyed college teachers believe that the most valuable personal qualities helping to solve problems of training and education will be the most significant and valuable personal qualities are professional competence (80.83\%), responsibility $(80.00 \%)$, honesty $(72.50 \%)$, friendliness $(63.33 \%)$, creativity $(40 \%)$, the ability to follow through $(35.00 \%)$, determination (19.17\%), entrepreneurship (11.67\%).

This focus on training and education does not meet the needs of nowadays reality, although human values, no doubt, remain a priority in the work of the teacher.

When describing themselves, vocational training teachers ranked their inherent character traits as follows: responsibility - (1), manners - (2), 
education - (3), independence - (4), patience - (5), self-discipline - (6), sociability - (7), self-management - (8), energy - (9), curiosity - (10), selfconfidence - (11), initiative - (12). The fact that the initiative and selfconfidence round out the list is alarming. In a rapidly changing world, society demands the system of vocational education to generate a teacher with the competitive abilities. It is difficult to imagine a teacher who can train a competitive specialist, if he is not confident, initiative and determined himself, because it is impossible to teach somebody things one is not able to do.

When answering the question, "How do you assess your role in the team?", $69.58 \%$ of respondents said that their colleagues defer to their opinion; $17.08 \%$ said that the authorities defer to their opinion, while $25.83 \%$ said that nothing depends on them. It makes us suspect that not all teachers are aware of their civic position in society and in the team, despite the fact that one of the educational functions performed by the teacher is to educate the civic-minded specialists.

\section{Discussion}

The problem of the professional qualities of the teacher has been investigated by a number of Russian scholars specialized in psychology and pedagogy. The most frequently discussed are emotionality, ${ }^{8}$ behavioral plasticity, ${ }^{9}$ the ability to understand students and guide them, ${ }^{10}$ mastering teaching methods, ${ }^{11}$ affection for children, ${ }^{12}$ empathy, ${ }^{13}$ and others. The issue investigated in this study was also examined in the works of G. I. Ibragimov ${ }^{14}$ and G. A. Shaikhutdinova, 15 who studied the personal and professional qualities of teachers in terms of the quality of training of middle managers. The analyzed studies on

8 Syritso, T. G. - Trusov, V. P. (1987), op. cit.

9 Kuzmina, N. V. (1990), op. cit.

10 Grishin, E. A. (1973). Professionalno-eticheskaya podgotovka uchitelya $v$ sisteme vysshego pedagogicheskogo obrazovaniya. Vladimir: Vladimir State Pedagogical Institute; Gonobolin, F. N. (1968), op. cit.

11 Pidkasistyy, P. I. - Portnov, M. L. (1998). Iskusstvo prepodavaniya. Pervaya kniga uchitelya. Moscow: Rospedagentstvo.

12 Amonashvili, Sh. A. (1996), op. cit.

13 Koziev, V. N. (1989). Psikhologicheskaya kompetentsiya uchitelya $\vee$ kontekste vzaimootnosheniy uchitelya i uchashchikhsya. In: Sukhobskaya, G. S. (ed.) Professionalnye potrebnosti uchitelya $v$ psikhologo-pedagogicheskikh znaniyakh. Sbornik nauchnykh trudov. Moscow: USSR Academy of Pedagogical Sciences, pp. 41-45. 
professional qualities of the teacher are highly important, since they were used in the development of the theoretical foundations of this study: the concept of pedagogical competence of the future vocational training teacher was formed, its basic structural components were described. These results enabled us to move on to the practical part of the study and carry out the pedagogical experiment.

The aspect examined in the present study - reveal of the influence of learning Humanities on the formation of professionally important personal qualities forming a part of the pedagogical competence of vocational training teachers, and in particular these defined in Federal State Educational Standards, has not been considered in the previous studies.

\section{Conclusions}

The analyzed indicators allowed us to draw the following conclusions:

- quite intense "rejuvenation" of the teaching staff takes place, as well as the transformation of their social, professional, and cultural level in accordance with the requirements of the time;

- nowadays, vocational training teacher is not just a knowledge translator, but a teacher and researcher involved in active professional development and self-education through participation in scientific conferences, workshops, round tables of different levels, as well as in research, educational, and methodical activity;

- vocational training teacher quite clearly realizes his/her role in the society and understands that he/she cannot be an authority and leader for students without sufficient knowledge and professional competence.

The findings confirmed the hypothesis of a positive impact of the Humanities on the development of professionally important qualities of the future vocational training teachers. In the next stages of the study on the basis of data described in this article, the concept of "pedagogical competence of the future vocational training teachers" was defined, its structural components were identified and described.

14 Ibragimov, G. I. (ed.) (2003), op. cit.

15 Shaikhutdinova, G. A. (2004), op. cit. 